\title{
WHAT IS MATHEMATICAL ANALYSIS?
}




\title{
DIMENSIONS OF MATHEMATICS
}

\section{What Is Mathematical Analysis?}

\author{
John Baylis
}

Nottingham Polytechnic

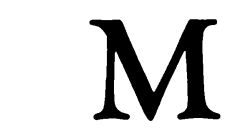

MACMILLAN 
All rights reserved. No reproduction, copy or transmission of this publication may be made without written permission.

No paragraph of this publication may be reproduced, copied or transmitted save with written permission or in accordance with the provisions of the Copyright, Designs and Patents Act 1988, or under the terms of any licence permitting limited copying issued by the Copyright Licensing Agency, 90 Tottenham Court Road, London W1P 9HE.

Any person who does any unauthorised act in relation to this publication may be liable to criminal prosecution and civil claims for damages.

First published 1991 by MACMILLAN EDUCATION LTD

Houndmills, Basingstoke, Hampshire RG21 2XS and London

Companies and representatives

throughout the world

ISBN 978-0-333-54064-0 ISBN 978-1-349-12063-5 (eBook)

DOI 10.1007/978-1-349-12063-5

A catalogue record for this book is available from the British Library. 
To Cathy 


\section{CONTENTS}

Preface

ix

\section{NUMBERS, LINES AND HOLES}

The aim of this chapter is to arrive at a definition of the set of real numbers, the set on which calculus and all subsequent developments are based. We have a brief look at some historical background, and give a fairly detailed account of the shortcomings of the rational number system. Finally, the incompleteness of the rationals is formulated explicitly and the reals - modelled by the set of infinite decimals - are shown to be complete

\section{CURVES - CONTINUOUS, DISCONTINUOUS AND} UNIMAGINABLE

This chapter examines various ways in which a function can be discontinuous, eventually arriving at the 'official' $\varepsilon-\delta$ definition of continuity. The usual pathological cases are considered and there is a discussion about the usefulness of continuous functions

3 ADDING UP FOREVER - PARADOXES AT INFINITY

Sequences and numerical series. The historically important examples. The Riemann rearrangement theorem for conditionally convergent series. A brief look at series convergence tests

Differentiability approached through continuity of slope. Desirable properties of functions differentiable over closed 
intervals. Graphical interpretation using the derivative. More pathological examples

5 PUTTING IT ALL TOGETHER - INTEGRATION

Integration as area, integration as backwards

differentiation: the connection. The integral as an 'easier' concept than area. History of integration as a rigorous theory. Setting up the Riemann integral. Conditions for integrability and some paradoxical examples

6 A BRIEF LOOK AT FURTHER DEVELOPMENTS OF ANALYSIS, AND SUGGESTIONS FOR FURTHER READING

Index

128 


\section{PREFACE}

\section{To teachers and learners}

Analysis has a bad image. It is a hard subject which students have always found difficult. Schools (justifiably) and many colleges (wrongly, I believe) have taken the view: analysis is hard so let's not do it. Many universities now seem to modify this slightly to: analysis is hard but unavoidable so let's delay it.

The first view produces a generation of students which has avoided some difficulties but missed out on the considerable satisfactions too. The second runs the risk that when analysis is finally tackled it is done in a great rush, though it is surely a necessary condition for student enjoyment that a long 'sink in' time is given.

By way of justification for this book, here are three defensible claims: (i) analysis is interesting, (ii) exposure to analytic ideas should come earlier rather than later than is currently the fashion, and (iii) there is a need for sympathetic texts at a level somewhat lower than the first 'formal' course in analysis. A book which is thorough and sufficiently complete to be a basis for a first year course is Mary Hart's Guide to Analysis in the Macmillan Mathematical Guides series. It is also very sympathetic to student needs. What is Mathematical Analysis? aims to put students into a confident and positive frame of mind for tackling such a course. It provides a taste of what analysis is about, and therefore must contain some fairly hard proofs. But these are embedded in far more chat than is customary in more formal texts. I hope that prospective students emerge from this book with a clear idea of why analysis is necessary and of the satisfaction it can provide.

\section{Important message to learners}

You will find the text regularly interrupted by mysterious things called PFTAs. These are 'Pauses For Thought and Action'! They are included in the firm belief that the best way to learn anything is to grapple with it 
yourself rather than passively absorb what others tell you. My recommendation is that you spend a minimum of a few minutes on each one as you come to them, before turning to the solution which generally appears on the same or the following page.

As for previous knowledge required to appreciate this book, a nodding acquaintance with calculus - just basic differentiation and integration would be useful background. There were several inconsistencies in early treatments of the calculus and one of the motivations for the development of anlysis was to remove these and render calculus 'respectable'. 